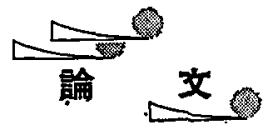

\title{
画像処理によるクリーンルーム内の気流解析*
}

\author{
井上正憲 ${ }^{* *}$ ，白井环也**，吉田隆紀**，岡田孝夫***
}

\section{Analysis of Airflow Pattern by Image Processing in Clean Room}

\author{
Masanori Inoue, Takuya SHIRAI, \\ Takanori YOSHIDA and Takao OKADA
}

\begin{abstract}
A simplified visualization system for measuring airflow patterns in clean rooms was developed. A tracer of distilled-water droplets with several micron diameter was radiated by a red-colored fluorescent light. The scattered light by the tracer was separated from all lights. And the scattered light was amplified and recorded by a video camera built-in real-time image processing. And this system enables us to visualize the airflow patterns in which there was an obscure contrast between the tracer and the background illumination.

The two-dimensional visualized images were converted into digital image-data, and processed numerically with an image pattern tracking method. The accuracy of the calculated vectors was influenced by the image-contrast. The effect of image-contrast on the accuracy was investigated by processing several images of different contrast. And the air-velocity measured with the image processing was compared with that measured with a laser doppler velocimeter.

From these analyzed results, it was concluded that the image of emphasized contrast enables to calculated exact vectors, air-velocity measured with image processing almost agreed with that measured with a laser doppler velocimeter, and the method was very useful for quantitative evaluation of various airflow patterns in clean rooms.
\end{abstract}

Key words : Air Stream Analysis, Measuring Technology, Clean Room, Flow Visualization, Image Processing

1.はじめに

クリーンルーム内の気流形状は, 室内の清浄度 や污染の広がりと密接に関係して扣り，その把握 はコンタミネーションコントロールの観点から重

*原稿受付 1993年 7 月 29 日

**高砂熱学工業㑣総合研究所

****正会員 高砂熟学工業㑣総合研究所
要である。気流形状を把握する有効な手法として は，従来より㖶などのトレーサを用いた可視化法 があるが，良好な可視化画像を得るために，背景 を暗くしたり，室内の照度を低下させるなどの， 特別な準備が必要であるといら問題点がある。し かし，奏際の工場内で気流を観察する場合，この ような背景の妈理を行らことが極めて困難な場合 が多い。その結果，背景の輝度が高い状況下で可 
視化を行わなければならず，良好な可視化画像を 得ることが困難になる。さらに得られた可視化画 像からは気流形状の定性的な情報しか得られな w。

本研究では，まず従来の可視化法で必要とされ た，可視化のための特別な準備を必要とせず，背 景が明るい室内でも容易に良質な気流の可視化画 像を得ることが可能な可視化手法”を考案し，そ の有効性を確認した。つぎに，この手法で得られ たクリーンルーム内気流の可視化画像を，近年急 速に進歩しているデジタル画像処理技術を用いて 处理し，画像データから速度分布(速度ベクトル) を定量的に解析するためのパターン追跡法2),31 の 概要，および解析結果の特性・解析例について報 告する。

\section{2. 可視化手法}

\section{1 可視化用光源}

可視化用の光源には，赤系統の波長を照射で き，安洒で比較的容易に入手できる赤色蛍光灯を 用いた。光源は気流観察方向の側方に設置し，雨 側からトレーサに照射している。一般的な半導体 用クリーンルームの照明に含まれている光の分光 強度を比較すると，この赤系統の波長域の分光強 度の割合は比較的少ない。このため，背景の照明 光と可視化用の赤色光は，後述するよらに，光学 的に容易に分離可能である。

Fig. 1 に可視化用光源（赤色蛍光灯）特よび

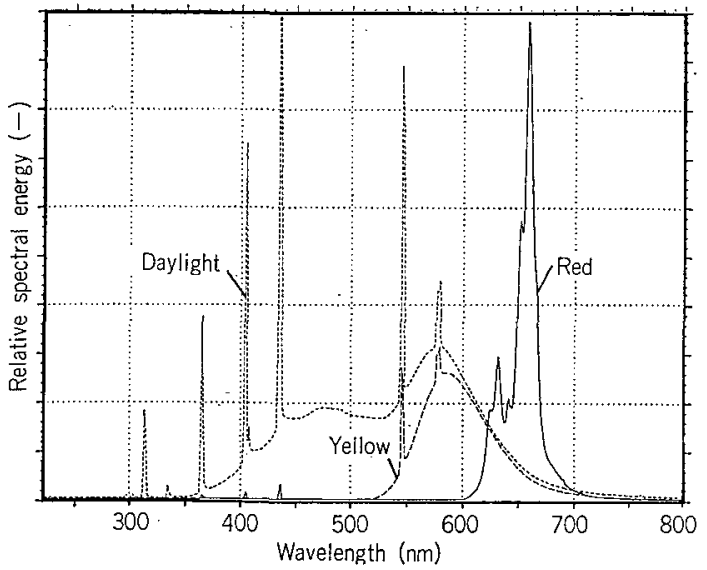

Fig. 1 Relative spectral energy distributions of fluorescent lamps
半導体工場内照明（昼白色，黄色営光灯）の分光 エネルギー分布の測定結果を示す。測定は，分光 分析器（大塚電子：MCPD 1000）を用いて, 各 蛍光灯の中心より $550 \mathrm{~mm}$ 離れた点で，220〜800 $\mathrm{nm}$ の範囲の波長について行った。図中に示され るように赤色蛍光灯のピーク波長は $650 \mathrm{~nm}$ 付近 にあり，室内照明のピーク波長とは，ずれている ことがわかる。

\section{2 受光系装置}

受光系は，可視波長領域に高い分光感度を持っ た撮像管を内蔵した TV カメラに，約 $620 \mathrm{~nm}$ 以 上の波長領域に高い透過特性を持った光学フィル 夕を組み合わせて，可視化用光源（赤色蛍光灯） から照射される光に含まれる波長だけを選択的に 取り达めるようにした。Fig. 2 に受光系に用い たTVカメラの撮像管の分光感度"), および光学 フィルタの分光透過率らを示す。これらの光学系 により、トレーサに照射されて散乱した $650 \mathrm{~nm}$ 付近の波長の光が，他の波長の光に比べて多く取 り込をれ，トレーサと背景のコントラストの向上 が図られる。Fig. 3 に昼白色蛍光灯と赤色蛍光 灯を並べて同時に点灯させた場合の，照射される 光の分光エネルギー分布と，同じ条件で可視化実 験に用いた光学フィルタを通した場合の分光エネ ルギー分布とその内訳を示す。光学フィルタを使 用しない場合は，2種類の営光灯から照射される 光を合成した分光エネルギー分布となっている が，光学フィルタを使用することで赤色の波長域 の光だけを選択的に取り込み，トレーサのコント ラストを低下させる原因となる室内照明（昼白色

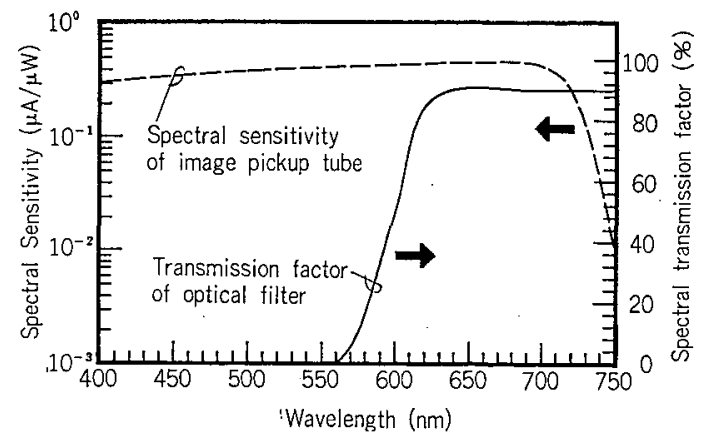

Fig. 2 Spectral sensitivity distributions of the image pickup tube and spectral transmission factor of the optical filter 


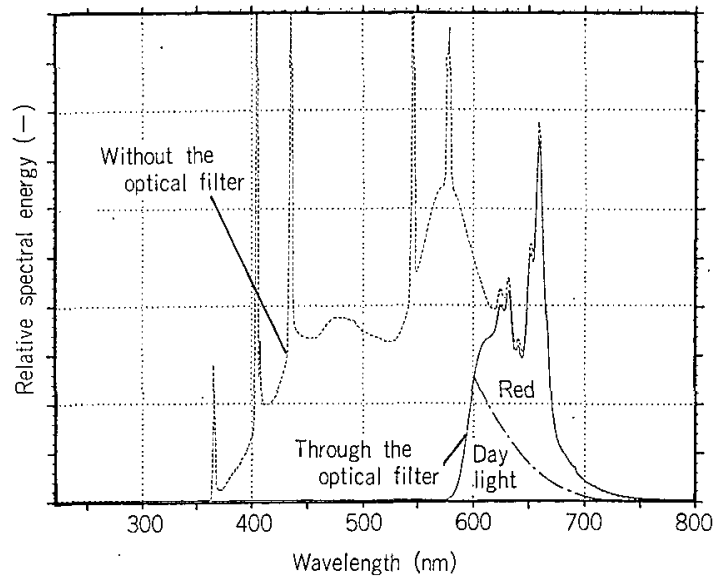

Fig. 3 Comparison between relative spectral energy distributions of fluorescent light through the optical filter and that of the direct light without optical filter

蛍光灯）光の割合が減少していることがわかる。

\section{3 トレーサ}

クリーンルーム内気流を可視化するためのトレ 一米粒子は, 表面污染防止の観点上限定される。 本研究では，純水ミス卜曰)を使用している。この ミストは, 液体窒素と純水の蒸気とを直接接触さ せることにより発生し，ノズルでクリーンルーム 気流中に供給している。またミトの温度は, 供 給前にクリーンルーム吹出し空気温度と泳注等し くなるよらに調整している。

供給直後のミストの空気力学的平均粒子径は， 2〜3 $\mu \mathrm{m}$ 程度である。赤色光に対するこれらの大 きさのトレーサ粒子の散乱特性は, 前方散乱が主 体となっている。可視化を行ら際に取り込んでい るのはトレーサ粒子の側方散乱光であり，その強 度は前方散乱光の約 100 分の 1 またはそれ以下之 なる゙。このように可視化に際してはかなり敩し い条件となっている。

\section{4 コントラスト強調}

2.2で述べたような受光系の改良で，トレーサ からの散乱光のみを分離し TVカメラに取り込 んでも，前述したトレーサ自体の散乱特性により 画質の大幅な向上は期待できない。そこで TV カメラにより撮影された可視化画像信号をリア ルタイム微分機能を持つコントラスト増強装直を 通すことによりコントラストを増強させた後に，
VTR にて記録する。この操作により，目視では ほとんど観察されないようなトレーサの動きも， 画像データとして記録したり，モニタで観察する ことが可能となっている。

以上に述べたように，筆者らの手法は，まずト レーサに照射した特定波長带の光だけを光学フィ ルタにより分離し選択的にカメラに取り込むこと により，トレーサのコントラストの低下を光学的 に防止し，さらに，得られた画像信号を微分処理 することによりトレーサ部分の信号を強調してい るところに特徵がある。その結果，トレーサを用 いた気流の可視化画像の画質を, 従来よりも大幅 に向上させることが可能となった。

\section{3. 画像処理システム}

\section{1 システム構成}

可視化および画像処理システムの構成を Fig. 4 に示す。前述のよらな手法で，ビデオテープに記 録された可視化画像より，まず速度ベクトル抽出 の対象となる画像を選び出す。この画像データ を，沉用画像処理装置により A-D 变换を行い， 計算用画像データとして光磁気ディスクに記録す る。気流の速度べクトルを得るための画像解析 は，連続した 2 画面を 1 組として，数組の画面を 処理している。つまり瞬間的なトレーサの動きを 各々解析し，その平均速度分布を求めることにな る。計算用画像データの画面数（組数）は，多い 注ぞ原理的に精度が向上するが，計算時間が長く なるため適度な画面数にとどめる。

ディジタル化された画像データは，パコンか

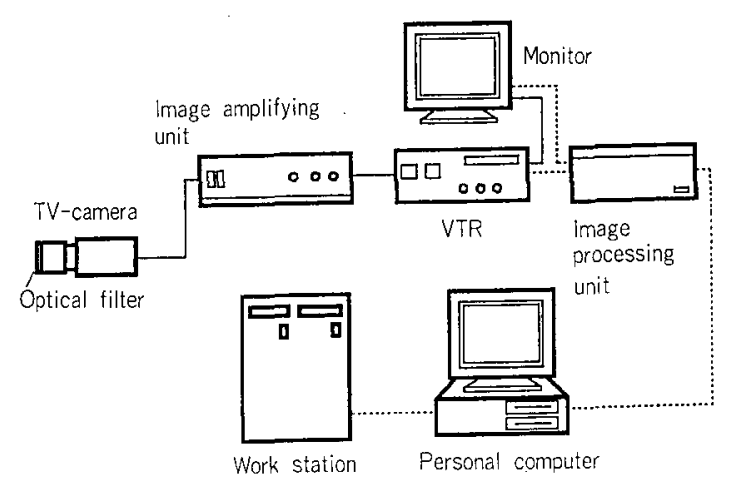

Fig. 4 Schematic diagram of the image processing system 
らワークステーションに転送後，パターン追跡法 (相関法)による画像解析アルゴリズムで処理す る。パターン追跡法の詳細については後述する。 解析後, 得られたベクトルデータ群は, ワークス テーションにて統計処理を行い不良なベクトルを 削除し，残ったベクトルを平均して 1 画面のべク トルデータを作成する。このデータはパソコン側 に返送され，再度不良なべクトルを削除 ${ }^{87}$ する。 不良なべクトルが削除されたポイントについて は，超りの良好なベクトルデータより内挿を行 亏。

\section{2 パターン追跡法（相関法）}

パターーン追跡法（相関法）とは，Fig. 5 以示 すような，異なった時刻の 2 画像中のある小頌域 の輝度分布の類似性を解析し，輝度分布パターン の移動方向と移動速度から速度ベクトルを抽出す る手法である。この手法は, 点 $a$ を心とする画 像小領域 $(n \times n$ 画素：以下 “基準マトリクス” と記す）の輝度分布パターンと，候補点 $b$ を中心 とする画像小領域（以下“候補マトリクス”之記 す）の輝度分布パターンの類似性の指標を, 移動 する可能性のあるすべての範囲について計算し， 最も可能性の高い候補点 $b$ を探し出すことであ る。一般的には，Fig. 6 に示されるような $n \times n$ の基準マトりクスと候補マトリクス内のすべての 点に関して, 式 (1)に示される 2 画像間の相互相

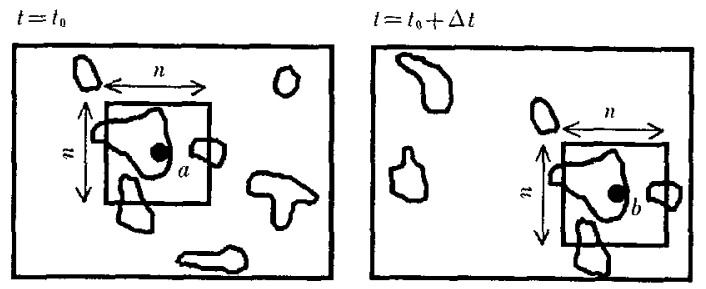

Fig. 5 Identified image fragments at the different times
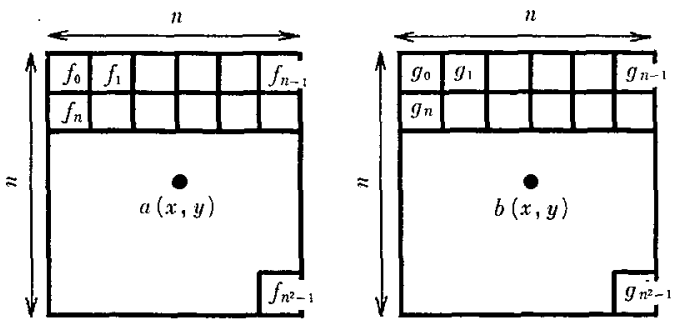

Fig. 6 Pixels in the corresponding image fragments
関係数きを計算し類似性の指標としている。

$$
R_{f g}(x, y)=\frac{\sum_{i=0}^{k}\left(f_{i}-\bar{f}_{i}\right) \cdot\left(g_{i}-\bar{g}_{i}\right)}{\left\{\sum_{i=0}^{k}\left(f_{i}-\bar{f}_{i}\right)^{2} \cdot \sum_{i=0}^{k}\left(g_{i}-\bar{g}_{i}\right)^{2}\right\}^{0.5}}
$$

$$
\text { ここで, } k=n^{2}-1
$$

しかし，本研究で用いる手法は，計算時間を短 縮するために考案された「輝度差の累積法」22,31 と呼ばれるもので, 式( 2 )に示される基準マトリ クスと候補マトリクス間で，対応する位置の画素 の輝度差の累積值を計算する。累積計算は, 輝度 の差の累積值 $D_{a}$ があるしきい值 $D_{\mathrm{c}}$ を越えるま で行い, そのときの累積回数 $N_{c}$ を類似性の指標 としている。つまり， $N_{c}$ が最大となる候補マト リクスの中心点が，パターン追跡法で求めたベク トルの終点となる。この手法では, 輝度羑の累積 值がすばやく增加するもの，つをりパターンが類 似していないものに対する計算は速い時点で打ち 切られるので, 結果的に計算時間は大幅に短縮さ れる。

$$
\begin{aligned}
& D_{a}=\sum_{i=0}^{m}\left|f_{i}-g_{i}\right| \\
& \text { ここで, } m=N_{c}-1
\end{aligned}
$$

\section{3 速度計測の分解能}

最終的に得られるトレーサーの速度 $V_{R}$ は, 式 （3）に示すように，画像上の移動速度を，実際の 架間での移動速度に換算して求める。

$$
V_{R}=\frac{\left(P_{X}{ }^{2}+P_{Y}^{2}\right)^{0.5}}{S \cdot \Delta t}
$$

ここで,

$P_{X}, P_{Y}$ : 連続画像間の $X, Y$ 方向の移動画素数 (pixels)

$S:$ 実空間と画像上の距離の換算值 (pixels $/ \mathrm{mm}$ )

$\Delta t:$ 連続画像間のサンプリング間隔 $(\mathrm{sec})$

また，計測の分解能 $R_{e}$ は垁際の空間での速度 $V_{R}$ を移動画素数で除したもので, 式(4)で示さ れる。

$$
R_{e}=\frac{V_{R}}{\left(P_{X^{2}}+P_{Y^{2}}\right)^{0.5}}=\frac{1}{S \cdot \Delta t}
$$

ここで, $S$ は可視化空間の面積に関係するパラメ 一タであり，面積を広くとると $S$ は小さくなり 
分解能は低下寸る。逆に, $\Delta t$ を大きくすると移 動画素数も大きくなり分解能は向上するが， $\Delta t$ を 大きくとりすぎると連続画像間でのトレーサの形 状が変化し，計測精度が著しく低下する。

\section{4. 速度分布計測}

\section{1 実験方法}

画像上のパターン追跡による速度分布計測を実 際のクリーンルームに応用する際に，速度ベクト ルデータの特性や算出精度をあらかじめ評価する ことが必要である。そこで実規模のクリーンルー ム（天井高 $2700 \mathrm{~mm}$ ) で気流の可視化を行い, 可視化画像を得た。可視化実験は, Fig. 7 亿示 す装置で行い，トレーサとして前述の純水ミスト を用いた。クリーンルーム内の気流は，天井吹き 出し床吸い込み方式の一方向流であり, 温湿度条 件は $23 \pm 0.5^{\circ} \mathrm{C}, 45 \pm 5 \%$ (RH) にとれぞれ設定 されている。可視化は, クリーンルーム内の照明 をすべて点灯し，背景はアイボリーホワイト調の 壁とした。壁面の照度は400〜 450ルクス ( $\mathrm{lx}$ ) 程 度であり, 純水ミストのトレーサを流した場合に 非常にコントラストがつきにくい背景で行った。

また，画像上のパターン追跡によって算出され たトレーサの移動速度の算出精度を検証するため に, レーザドップラ流速計 ${ }^{10)}$ (KANOMAX : SYSTEM 8800) によるトレーサ（純水ミスト）

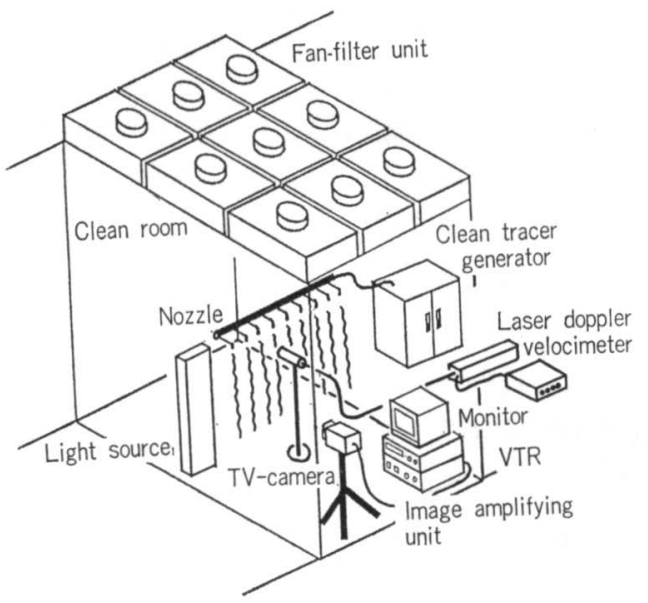

Fig. 7 Schematic diagram of airflow visualization system in a clean room
の個々の移動速度の同時計測を行った。

\section{2 可視化画像の画質 (コントラスト)}

最初に，可視化画像の画質（コントラスト）が 画像上のパターン追跡による速度ベクトルの算出 結果におよぼす影響を解析した。気流形状および 実際のトレーサ濃度が同じ空間の気流を，3 種類 の手法によって可視化した。そして得られた各画 像について解析を行った。第1の画像は筆者らか゚ 提案している手法, つまり赤色蛍光灯を可視化光 源とし, 光学フィルタ分離と画像データの微分処 理によるものである。第 2 の画像は赤色蛍光灯を 可視化光源とし光学フィルタ分離による手法（微 分処理は行っていない)，第 3 の画像は昼白色蛍 光灯を可視化光源とした手法 (光学フィルタ分離 之微分処理は行っていない）によって得られた可 視化画像である。

Fig. 8 に解析を行った第 1 の画像を示す。Fig.

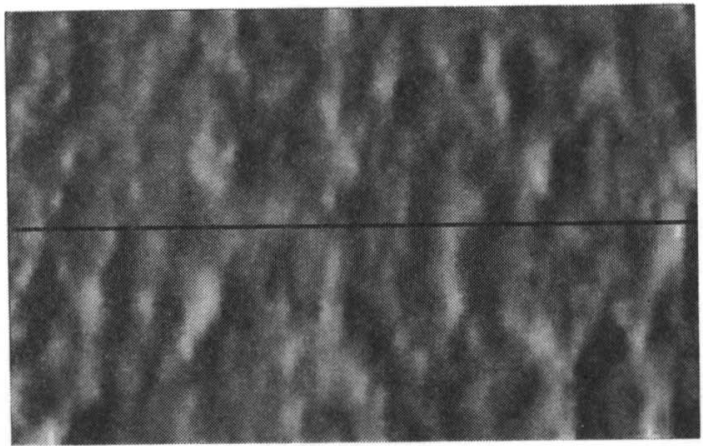

Fig. 8 Original image obtained with present visualization method

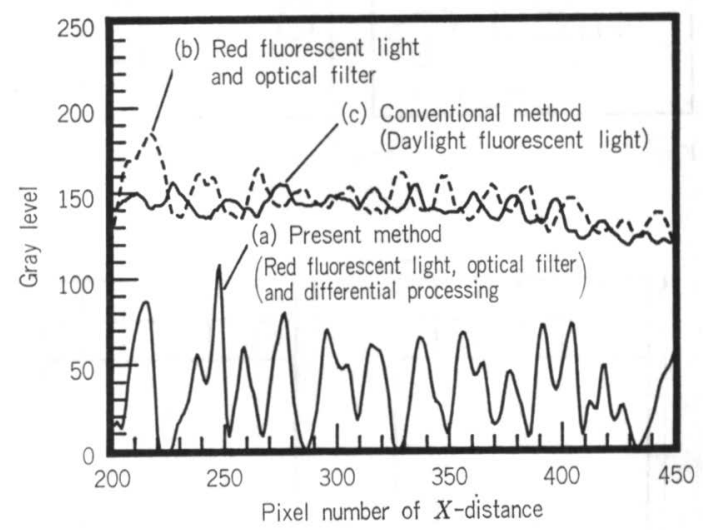

Fig. 9 Comparison of gray levels in the conventional and present visualization method 
8 の画像中のライン上の輝度分布(a)之第 2 , 第 3 の画像中の同一ライン上の輝度分布(b)，(c)を Fig. 9 に示す。輝度レベルは，黑を0，白を 255 とし 256のレベルに分割されている。Fig. 9 中の山部 がトレーサの部分で，谷部が背景の部分であり， 山部と谷部の差が大きい程，画質(ユントラス ト）が良好となる。第 1 〜第 3 の画像に拈いて， トレーサと背景の輝度差は，それぞれ50～70，20 〜30，10〜20程度となっている。

このような画質（コントラスト）が異なる 3 種 類の画像上でパターン追跡（輝度差の累積法）を 行った場合の，過䛊ベクトルの出現割合之画質 （コントラスト）の関係を Fig. 10 に示す。画 質（コントラスト）を表すパラメータとして，画 像上の隣接した各画素間 $(x, y$ 力向) の輝度差 の平均值を用いている。鮮明な画像ほど輝度差の 平均値は高くなる。この結果より，可視化画像の 画質（コントラスト）は，画像上のパターン追跡 による速度ベクトルの算出能力に大きく影響して いることがわかる。さらに，本報で提案している 可視化手法によって，速度ベクトルの算出精度の 大幅な向上が図れることも明らかになった。

\section{3 速度計測データの分布}

各画像の組から得られる速度分布は, 3.1 で述 ベたよらにある瞬間の速度分布となる。そこで, 速度計測データがどのような分布をとるかを調べ

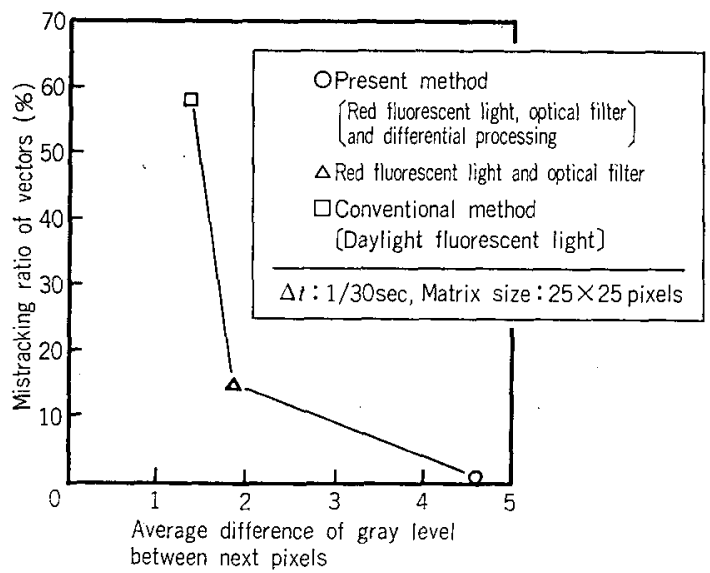

Fig. 10 Relationship between mistracking ratio of vectors and average difference of gray level between next pixels
た。

まず，可視化領域の任意の位置のトレーサ粒子 の水平 $(x)$-重直 $(y)$ 方向の移動速度を, レー ザードップラ流速計で測定した。測定は，約 1000 個の純水ミストについて行った。

らぎに，レーザドップラ流速計の測定ポイント を中心とした $35 \mathrm{~mm} \times 35 \mathrm{~mm}$ (奏空間) の範囲 における可視化画像を用いパターン追跡法により 解析した。各可視化画像は 4 分間撮影されて特 り，約 5 秒間隔で 1 組（連続した 2 画面）ずつサ ンプリング（合計49組）をした。レーサドップラ 流速計による測定沶よび画像上のパターン追跡に より得られた速度べクトルデータの水平 $(x) \cdot$ 垂 淔 $(y)$ 成分のデータの分布在 Fig. 11 (a), (b) に示す。図中の $V_{d}, V_{i}$ は，各々レーザドップラ 流速計，画像上のパターン追跡による結果であ ъ。

レーザドッブラ流速計と画像上のパターン追跡 による速度分布を比べてみると，速度の水平・垂

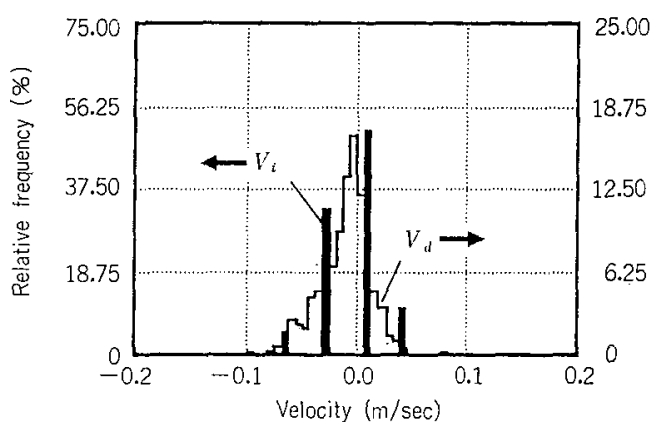

(a)

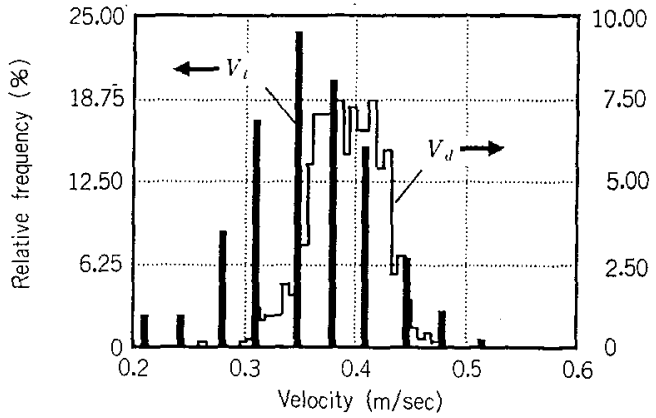

(b)

(a) Horizontal component of the velocity (b) Vertical component of the velocity

Fig. 11 Velocity distributions measured with a laser doppler velocimeter $(V d)$ and the image processing $\left(V_{i}\right)$ in a down flow clean room 
直成分とも平均值付近をピークに両側に広がる， 一山型となっており，各々よく類似した分布とな っている。このことより，画像上のパターン追跡 によって得られたベクトルデータは，トレーサの 移動速度分布をよく解析できていることがわか る。また，画像上のパターン追跡による速度分布 が離散的な値となっているのは分解能（1画素 分）に起因するるのである。

\section{4 計測精度}

クリーソルーム気流の可視化画像上でのパター ン追跡による速度計測の精度を調べるためにレ ーザドップラ流速計の計測結果との比較を行っ た。画像上のパターン追跡の精度に対するマトリ クスサイズや画像間の時間間隔の影響について

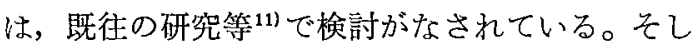
てこれらの条件の最適值は，流れの速度や乱れの 大きさ，トレーサの濃度分布パターン等によって 異なる。ここでは，マトリクスサイズ $25 \times 25$ 画 素, 画像間の時間間隔は $1 / 30$ 秒とし移動画素数が 低速部で10画素以上となるように設定した。そし てこれらの条件は固定とした。

可視化とレーザドップラ流速計の計測は，測定 条件を揃えるために同時に行った。また，計測空 間は乱れの比較的少ない一様流の部分とした。画 像上のパターン追跡による速度の算出は，レーザ ドップラー流速計の計測ポイント近傍 5 点のデー タの平均値である。また，各点での速度の算出に

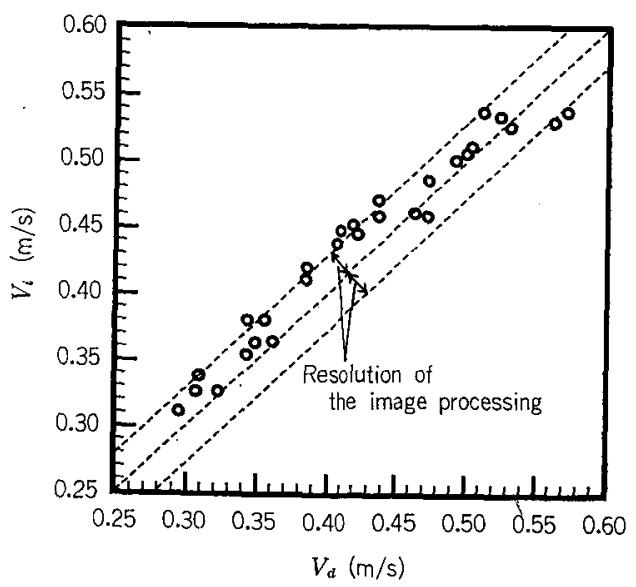

Fig. 12 Comparison between the vertical velocity component measured with the image processing ( $V i)$ and that measured with a laser doppler velocimeter $(V d)$
は，20組の画像を用い，得られた速度ベクトルデ 一タ群を統計処理した。な招，計測は垂直成分 (y) のみについて行った。

Fig. 12 に計測結果を示す。横軸に,レーザド ップラ流速計で計測した平均速度 $V_{d}$ を，縦軸に 画像上のパターン追跡で求めた平均速度 $V_{i}$ を示 す。画像上のパターン追跡による平均速度 $V_{i}$ は, レーザドップラ流速計で計測した平均速度 $V_{d}$ と ほぼ一致して和り，良好な結果が得られた。レー ザドップラ流速計を基準とした偏差率（|V $V_{i}-V_{d} \mid$ $\left\langle\left|V_{d}\right|\right)$ は，最大で $10.7 \%$ ，平均で $5.0 \%$ となっ ている。また，画像上のパターン追跡による速度 計測分解能は, 式(4)より $28.6 \mathrm{~mm} / \mathrm{sec}$ であ り，Fig. 12 中の点線で示した幅である。しか し，速度分布が Fig. 11(a)，(b)に示すような画像 上のパターン追跡の計測分解能の数倍の分布幅を 持っている場合（本実験の条件では，計測分解能 $=0.61 \sigma_{d} \sim 2.22 \sigma_{d}\left(\sigma_{d}:\right.$ レーザドップラ流速計で 得られた速度分布データの標準偏差）となってい る。）には，画像上のパターン追跡による速度計 測に用いる画像組数を大きくして統計处理を行ら ことにより，分解能による䛊差を無視できる程度

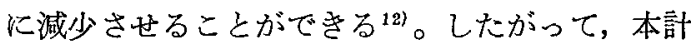
測で生じた誤差には，分解能に起因するるのは極 めて少ないと考光られる。これらの誤差の多く は, 画像上のパターン追跡時のトレーサのパター ンの崩れ・変形等によって，パターン追跡の精度 が低下したことによると考えられる。

\section{5 装置䞤りの速度分布の計測}

Fig. 7 に示したよらな実規模のクリーンルー 厶内に装置模型を設置し，その迴りの気流の可視 化を行った。そして得られた可視化画像を用いて 画像上のパターン追跡により平均速度分布を求め た。なお，装置模型としては，林置きの場合だけ でなく，空中に浮いた状態のロボットアームのよ らな障害物も想定した。画像上のパターン追跡を 行らために使用した画像データの画面数は，合計 14組（28画面）であり，すべて等時間間隔でサン プリングされて和り，連続した 2 画面を1組とし ている。

Fig. 13 は，朱上に置かれ，装置上面に段差の ある装圆模型の迴りの解析結果でめる。装置によ 
り気流が遮られ，装置上方で左右に分かれて流 れ, さらに段差の部分で小さな渦の発生が確認で きる。また, 装置上面で流れが停滞している様子
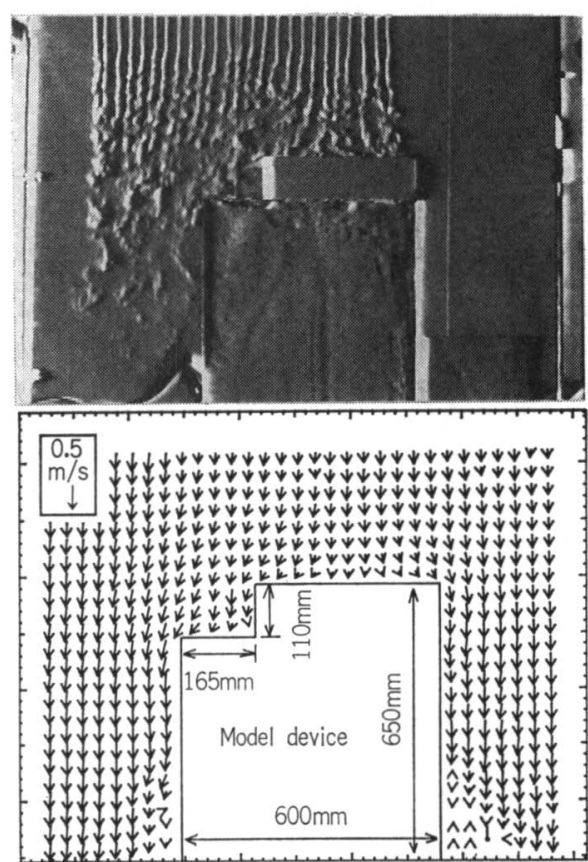

… Fig. 13 Airflow pattern around the model device with a stepwise outline
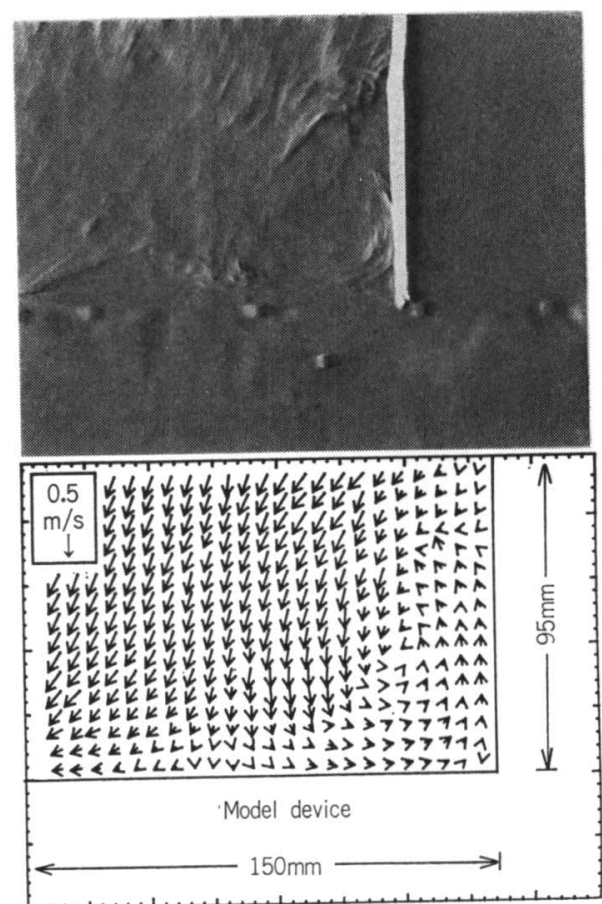

Fig. 14 Detailed the vortex in Fig. 13
るわかる。

Fig. 14 は，Fig. 13 の装置上面の段差部分を 拡大して解析した結果であり，拡大したことによ り，段差部分で生じた渦の様子が良く解析されて いる。

Fig. 15 は, 円形断面を持つロボットアームの 装置模型迴りについて，解析を行った結果であ る。アームに沿った気流の様子や，アーム下方で の乱れが良く解析されている。ただし, アーム直 下にはトレーサが回り込まないために,この部分 の解析はできていない。

\section{5.おわりに}

従来の可視化法で必要とされた，可視化のため の特別な準備，たとえば，背景を暗くしたり，照 明を落としたりすることを必要としない可視化シ ステムを開発した。さらに，画像上でのパターン 追跡（輝度差の累積法）により, 速度ベクトルを 算出する場合の，算出精度に対する可視化画像の 画質（コントラスト）の影響や, 算出された速度 分布の特徴拈よび算出精度について明らかにし た。そして, 本可視化システムによる画像で, 大

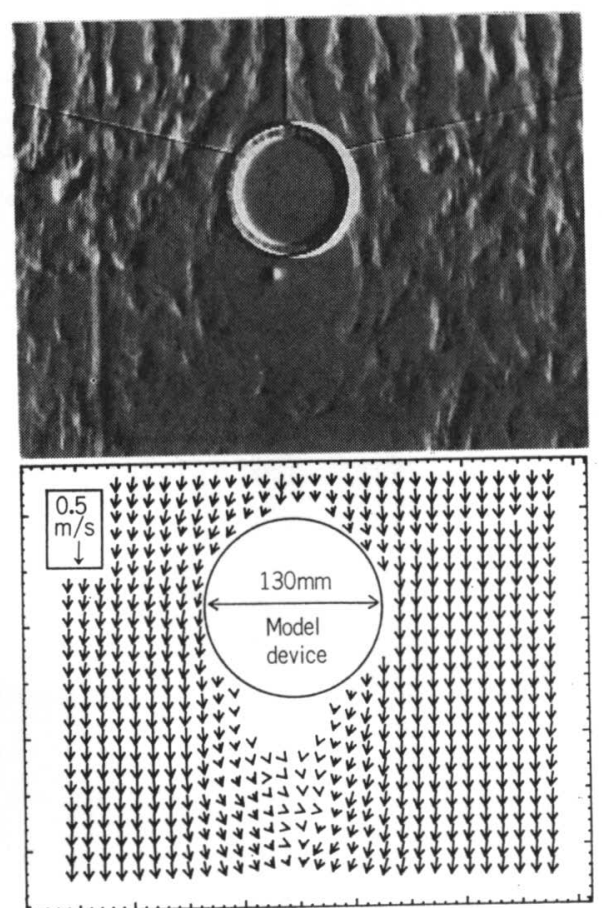

Fig. 15 Airflow pattern around a circular cylinder 
幅なパターン追跡精度の向上を図れることを確認 できた。

このような手法を用いて，クリーンルーム内の 装置模型迴りの代表的な気流の可視化を行い，良 好な可視化画像を得ることができた。さらに画像 上のパターソ追跡を行い速度分布を算出した結 果, 流れの特性が良く解析されて扣り，クリーン ルーム内低速気流の平均速度分布を定量的に把握 する手法としては，有効であるとが確認され た。また，画像上のパターン追跡による速度分布 の算出条件に関しては，流れの状態により異なる ため，可視化画像よりある程度推定した上で，解 析を進めていくことが重要である。

\section{参考文献}

1）井上ほか：クリーンルーム内装盾迥りの気流に関する研
究, 日本機械学会流体工学部門講演会諈演論文集, No. 920-68 (1992) 349-351

2) 幸ほか：簡易相関処理による煙可視化像からの気流速发の 計測，流九の可視化，8-30 (1988) 293-296

3）加賀昭和：辉度差の累皘法，可視化情報学会第 3 回手法別 講習会教材 (1991) 18-22

4）洪松ホトニクス㑣：高性能・多機能ビデオカメラカタログ

5) (林ケンュー:カラーフィルターガラスカタログ

6) 杉田ほか：クリーンルーム気流可視化用トレーサー，第 6 回エアロゾル科学・技術研究討論会 (1988) 22-25

7) William C. Hinds (早川一也訳) : エアロゾルテクノロシ (1985) 315, 井上書院

8）木村ほか：ニューラルネットワークによる過誤ベクトルの 判定, 日本機械学会流体工学部門講演会諈演論文集, No. 920-68 (1992) 310-312

9）林村か，相関を利用した流れの画像計測，流れの可視 化, 6-22 (1986) 269-272

10）日本機会学会編：技術資料 流体計測法（1985）142-149

11）加賀：画像処理を用いる速度計測システムの開発に関する 研究, 文部省科学研究費補助金 (一般研究C) 研究成果報 告書 (1990)

12）吉澤康和：新しい謓差論（1989）110-118, 共立出版 